\title{
Management of continental saline ecosystems in the Republic of Serbia - Are these ecosystems suitable for nature-based tourism?
}

\author{
Milica Luković ${ }^{1 *}$, Urban Šilc ${ }^{2}$ \\ ${ }^{1}$ University of Kragujevac, Faculty of Hotel Management and Tourism in Vrnjačka Banja, \\ Serbia \\ ${ }^{2}$ ZRC SAZU, Institute of Biology, Ljubljana, Slovenia
}

\begin{abstract}
Continental saline habitats represent unique, authentic and rare ecosystems. These ecosystems are typically distributed in arid and semi-arid regions; however, they are also found in inland areas in temperate climate zones. Usually, the general public is not familiar with this particular type of ecosystem. In order to present saline habitats to touris ts, a broadly applied method of ecosystemsuitability as sessment (ESI - ecos ys tem suitability index) was used and adjusted to the purposes of this research. The res earch aims to es timate the naturebased tourism potentials of selected sites. Thus, six representative halophytic habitats distributed along the geographic gradient, from the Pannonian Plain to the south of Serbia, were chosen. In terms of each site, seven indicators (e.g., flora and vegetation, bird fauna, landscape, protection status, accessibility, and ecotourism facilities), important for naturebased tourism, were analyzed. The results show that the Pannonian saline habitats have greater opportunities for development of this type of tourism in almost all categories compared to southern sites.
\end{abstract}

Keywords: saline habitats, nature-based tourism, ecosys tem suitability index JEL classification: Q57

\section{Upravljanje slatinskim ekosistemima u Republici Srbiji - Da li su pogodni za turizam zasnovan na prirodnim resursima?}

Sažetak: Kontinentalna slatinska područja predstavljaju jedinstvene, autentične i retke ekosisteme. Ova područja su svojstvena aridnim i semiaridnim klimats kim zonama, ali se sporadično pojavljuju duboko u kontinentu umerene zone. Često je ova vrsta ekosistema nepoznata široj populaciji. U svrhu približavanja slatinskih staništa turistima korišćen je široko primenljivan metod procene podobnosti ekosistema za turizam zas novan na prirodnim resurs ima. Cilj ovog is traživanja je procena ekoturis tičkih potencijala odabranih područja. Za

* milica.petrovic@kg.ac.rs

This article is an open access article distributed under the terms and conditions of the Creative Commons Attribution (CC BY) license (http://creativecommons.org/licenses/by/4.0/). 
potrebe istraživanja izdvojeno je šest reprezentativnih slatinskih lokaliteta duž geografskog gradijenta, od Panonske nizije do juga Srbije. Za svaki lokalitet je analizirano sedam kriterijuma (flora i vegetacija, fauna ptica, predeo, status zaštite, pristup i ekoturistička infrastruktura) koji su značajni za ekoturizam. Rezultati su pokazali da panonske slatine imaju veći ekoturis tički potencijal po gotovo svimanaliziranim kriterijumima u poređenju sa južnim slatinama.

Ključne reči: slatinska područja, ekoturizam, indeks podobnosti ekosistema JEL klasifikacija: Q57

\section{Introduction}

Saline ecos ystems are primarily dis tributed in arid and semi-arid regions, but they could be found in all climate zones as a type of intrazonal vegetation. Generally, around the globe, naturally occurring saline areas, salt affected soils include salt marshes, salt coastal wetlands or salt sandy shores, as well as continental salt marshes and meadows/pastures. Flora and vegetation growing in salt-affected areas is referred to as halophytic flora and vegetation. Halophytes are remarkable group of plants that have developed special abilities and mechanis ms to cope with extremely high salt concentrations (Rančić et al., 2019). The fact is that only a s mall number of plants can grow in conditions of increased salinity. The habitats with halophytic flora and vegetation are indeed captivating landscapes, bearing no resemblance to any other attractive ecosystem. Saline habitats, as rare and specific ecosystems, have an important role and are valuable for preserving the natural habitats of halophytic species and communities, inclu ding the regulatory and supporting functions, as well as a great potential for tourism development. Because of their authenticity, representativeness and rarity, saline habitats can be ranked as an ecotouris m attraction.

In the Republic of Serbia, these rare saline habitats are primarily distributed in the Pannonian plane, where different salt-affected soil types occupy the surface of 15,000 to 25,000 ha. Most of themare located in Bačka, then in Banat and fewer in Srem. The highest percentage of solonetztype of soil is found in Banat (68,000 ha), less in Bačka (4000 ha) and even less in Srem (3,000 ha) (Đorđević \& Radmanović, 2016). Saline habitats appear as small mos aically distributed patches in the southern part of Serbia, near the Prokuplje, Vranje and Bujanovac. Natural saline ecosystems are among the most endangered and fragile habitats in Serbia, due to high anthropogenic pressure, including the formation of reclamation canals, changes in the water regime, conversion of salt-affected soils into arable land or garbage dumps, intensive grazing, invasion of weeds and ruderal flora, burning, construction etc. According to (Zlatković et al., 2005), to this day, rare saline habitats have survived in the area of Vojvodina and few of themin the south of Serbia. Besides well-affirmed ecotourism attractions, saline habitats could be seen as captivating multifunctional additions in tourism offer, contributing to nature conservation and education, as well as boosting the economy and diversification of economic activities in local communities.

In general, saline habitats, especially coastal and continental salt marshes, have similar characteristics to wetlands that are recognized as an ecotouris mattraction. Wetlands, as well as salt marshes, are ranked as productive ecosystems for their biodiversity richness, especially in plant and bird species, and very attractive landscapes. According to biodiversity and ecosystemfeatures, these types of habitats could be considered as a place of naturebased tourismand recreation. Coping and replicating a well-established model of wetland ecotourism supports development of saline habitats as ecotourism sites that provide advantages and potentials for local communities through the diversification of the local economy, as well as ensures ecological benefits for these sites. 

ecosystems suitable for nature-based tourism? - Hotel and Tourism Management, 2021, Vol. 9, No. 2: 37-49.

The aim of this study is to review and assess suitability of selected saline habitats in the Republic of Serbia for nature-based tourism. The research was based on the hypothesis that the remaining natural and autochthonous saline habitats possess a variety of natural values (original flora, fauna, landscapes, etc.) suitable to be considered as nature-based tourism objects providing a range of ecological and economic benefits.

\section{The ore tical background}

Throu ghout the world, saline habitats refer to coastal salt marshes called lagoons, mangrove habitats, sand dunes, continental halophytic ecosystems with specific halophytic flora and vegetation adapted to survive in the range of environmental conditions - edaphic rather than climatic, as well as wet saline habitats, deserts and salt meadows in the temperate climate zone (González, 2020; O’Leary \& Glenn 1994). Saline habitats are characterized by a range of roles in terms of ecosystem functions and services. Besides maintaining ecosystem balance, they have a variety of commercial values (Nikalje et al., 2019). Saline meadows are traditionally used for lives tock grazing as well as hay supply for winterfeed. It is known that many halophytes are suitable for pharmaceuticals or industrial chemicals production, as well as for raw materials such as fiber, biomass, biofuel, etc. (Dagar, 2005). Halophytes support human well-being through food, fodder, non-timber forest products (Zhao et al., 2011). They are als o a source of medicinal and aromatic plants, spices, construction materials, energy, and ecosystem support. Their role in $\mathrm{CO}_{2}$ sequestration, landscaping, natural purification, environmental protection and wild life support is very important (Luković et al., 2021). In addition, a number of recent studies examined chemical suitability of halophytes for human nutrition (Barreira et al., 2017). The demand for halophytic products on the European market is growing. Some halophytic species, e.g., Salicornia europaea, Salicorniafruticose, Suaeda maritima, Aster sp. genus Atriplex have already become a part of the new and attractive cuis ine. In some tourist centers they are included in the gastronomic offer and often used in salads, as spices, side dishes and etc., due to their health benefits for the consumers (Petropoulos et al., 2018; Srivarathan et al., 2020).

Several studies (e.g., Lasabuda et al., 2019) investigated ecotourism suitability of mangrove habitats (as one of the saline types). Mangrove ecosystems are becoming, in recent times, a subject of interest as touris m destinations. The growing popularity of mangroves and the findings of the mentioned studies are used to promote a sustainable approach, nature, and wildlife conservation (Nelly et al., 2019). In addition, certain studies were conducted to determine marine ecotourism suitability (Johana et al., 2017; Tanto et al., 2018). By examining the studies, practice, knowledge, and experience in wetlands ecotourism, as well as a new approach in man grove ecosystemas an ecotourism destination, the authors came up with the idea to analyze potentials and suitability of continental saline habitats in this res pect. Salt marches and salt meadows (steppe) are inconsistently distributed in the territory of the Republic of Serbia (the Pannonian plane and southern Serbia). Salt marches represent one of the floris tic centers in the Republic of Serbia. The land scape of saline habitats complements several shallow alkaline lakes. These rare inland habitats have existed in the Carpathian Basin since the last Ice Age (Šefferová Stanová et al., 2008). The unusual plant species characteristic for marine areas rather than the country which has no access to the sea, together with sparkly-crystal surfaces formed due to the increased salt concentration in the soil and high evaporation of groundwater during summer, make these areas unique and very attractive. Alkaline lakes are habitats of many different bird species that could be the subject of interest of a wider group of ecotouris ts (Ecsedi et al., 2004). Due to limited geographical distribution and anthropogenic factors, they belong to the group of the most threatened habitats in Europe. Only several sites are under protection, while the rest of them are competing with agriculture orhuman impact. In recent time there has been some progres s 
towards protecting such rare ecosystems. Nature-based tourismcould be the solution for the promotion of educational aspects including gaining practical experience, getting opportunities to work with scientists, involvement in data collection and active participation in nature conservation. Ecotouris m activities offer travel opportunities to touris ts who are fond of nature and willing to contribute to conservation, as well as open to learning about rare habitats, country and culture (Lowman, 2004). As res ponsible tourism branch, naturebased tourismis a driving force and a safeguard of the ecosystem integrity and producer of economic benefits for local communities that can encourage conservation (Nash, 2001). Such rare ecosystems are always attractive for eco-tourists, and their "placing on the market" must be strictly regulated by conservation s trategies and sustainable use of natural res ources, even though nature-based tourismhas les s harmful impacts (Sánchez-Prieto et al., 2021). To avoid any kind of negative impact of touris $m$, it is necessary to apply sustainable development models, which imply using natural resources "that meet [s] all economic, social, and aesthetic needs while res pecting cultural integrity, basic ecological processes, biolo gical diversity, and lifestyles" (Raičević \& Marjanović, 2021, p. 92). Saline ecosystems as a part of rural ambient include numerous additional activities arranged by rural hosts such as hunting, fishing, horse-riding, walking, even wellness (Tomić et al., 2020).

\section{Mate rials and methods}

\subsection{Study area}

The study area includes two representative continental saline habitats located in the Pannonian plane (Slano Kopovo and Rus anda) and four habitats geographically dis tributed in southern Serbia (Lalinačka slatina, Oblačinska slatina, Bresničić and Aleksandrovačka slatina) (Figure 1).

Slano Kopovo represents one of the most important saline habitats in the Republic of Serbia according to the level of preservation of authenticity and nature. Slano Kopovo is located in northwestern Banat (Province of Vojvodina) near the city of Novi Bečej. This saline habitat is also important for its saline lake. The lake (together with its surrounding area) was declared a natural as set of exceptional importance and classified in the first category of protection at the end of 2001, while according to the classification of the International Union for Conservation of Nature (IUCN) it belongs to category IV - habitats and other managed areas. In addition, Slano Kopovo was listed under the Ramsar Convention in 2004 as a wetland of international importance. It is characterized by a steppe-continental climate, as well as all other areas in Vojvodina. During the summer months, the lake usually dries up and a salt crust forms on the floor of the lake. This site is a typical example of extreme saline habitats which are characterized by a mixture of salt marches and salt steppe vegetation. Many plant species characteris tic of this type of vegetation are rare or endemic species and are protected by the law (saltwort-Salsola soda, sea-blites-Suaeda maritima, glasswortSalicornia europaea, Schwartzerbergian's plantain-Plantago schwartyerbergiana etc.). In addition, Slano Kopovo is one of the most important bird habitats in Serbia.

Lake Rusanda is one of the saline habitats in Banat region. This lake is part of the Rusanda Nature Park and is surrounded by meadows and anthropogenicaly altered habitats. The RusandaSpa and its Special Hospital for Rehabilitation, located in the centre of the Nature Park, use mineral peloid in different medical and spa treatments. This lake represents one of the last remaining alkaline lakes in Serbia. Lake Rus anda is located near the town of Melenci and resembles the shape of the letter $\mathrm{C}$. It is inhabited by numerous bird species, and it is a migratory stopover. The shore of Rus anda lake is overgrown with the Pannonian endemic seashore aster - Aster tripolium s sp. panonnicus and succulent halophy tes. 
Saline habitats of central and southern Serbia include limited number of sites distributed around Prokuplje and along the valley of the South Morava, near Vranje and Bujanovac. These complex salt habitats include several sites: Lalinačka slatina, Oblačinska slatina, Bresničić and Aleksandrovačka slatina, that are the subject of the research in this study. These saline habitats are mosaically distributed in the shape of small patches around the source of salt waters. A few saline sites in this region belong to vulnerable and threatened habitats. Flora and vegetation in this region differ from those in the Pannonian region in a biogeographical sense. The impact of sub-mediterranean climate has produced specific conditions. Floristic differences are reflected in the presence of rare and endemic species such as Camphorosmamonspeliaca, Satchys milanii, Puccineliafestuciformis s sp. Convolute etc., but also in the absence of succulent halophytic flora.

Figure 1: Geographical distribution of selected saline sites

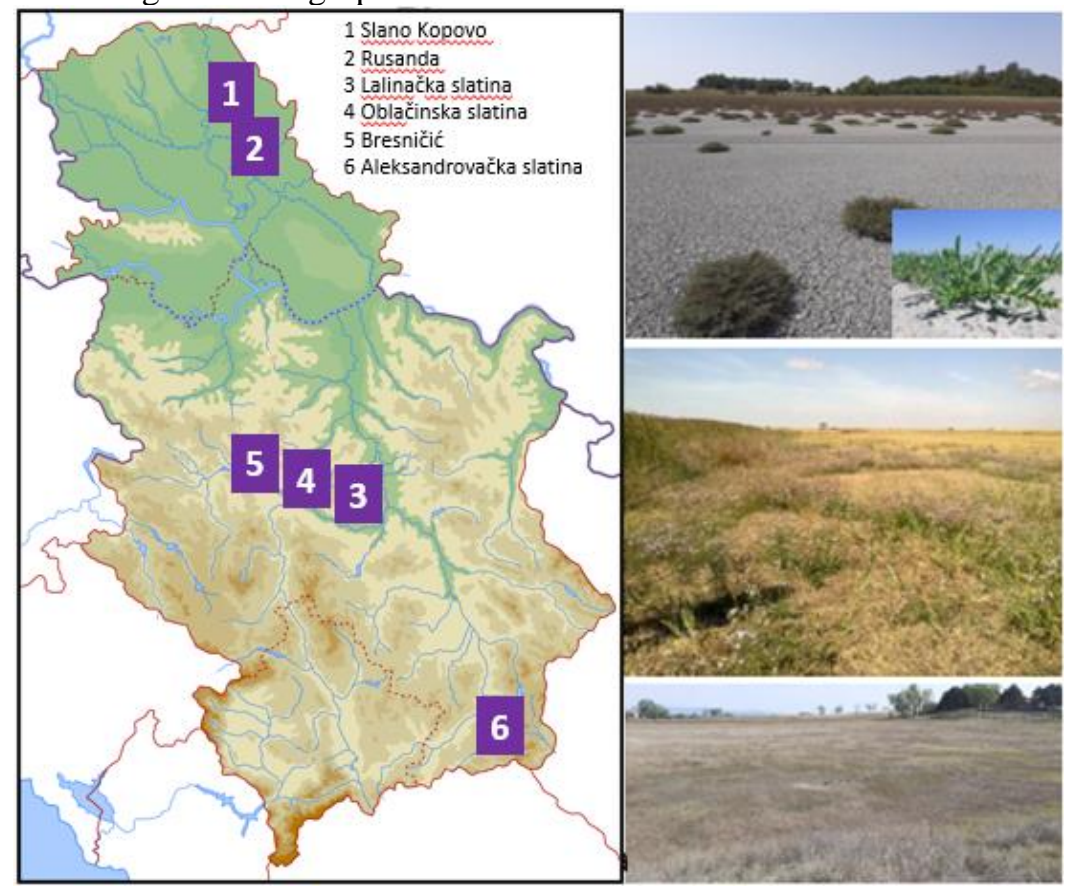

Source: Author's research (author's photographs: 1. Slano Kopovo, 2020; 2. Rus anda, 2015; 3. Oblačinska slatina, 2020)

\subsection{Data collecting method}

Neces sary datasets were collected during the comprehensive research of saline habitats in the Republic of Serbia (2012-2015) and these include: vegetation patterns (communities, density, cover), floris tic data, data on protection or endangerment, geospatial information, as well as community information such as acces sibility to main roads or ecotouris m facilities. Data on flora and vegetation were collected using the standard Braun-Blaquet method (Braun-Blaquet, 1932) widely used in the science of phytocoenology. The dataon more than 300 relevés were collected on the whole territory and stored in vegetation databases (GIVD, Dajić-Stevanović et al., 2012). For the purpose of this research, 16 relevés were examined for each of the selected sites. Data on fauna were collected fro ms econdary literature sources. Geospatial and communities' data were collected using GPS, fieldwork observation and national infras tructure of geos patial data (National Spatial Data Infrastructure, 2021). 


\subsection{Data analysis}

Data analysis was conducted based on similar studies (e.g., Nelly et al., 2020; Pin et al., 2021) with adjustment of selected parameters to this research. The final set of parameters/variables include vegetation cover, percentage of endemic, rare or attractive plant species per relevé, bird diversity, percentage of modified landscapes, category of the protected area, accessibility in terms of main roads vicinity and ecotourism infrastructure such as info tables, viewpoints, bridges, towers etc. Ecotouris m suitability assessment was carried out using ESI (ecos ys tem suitability index for continental saline habitats).

$$
\mathrm{ESI}=\sum(\mathrm{Ni} / \mathrm{Nmax}) \times 100 \%
$$

$\mathrm{N}_{i}=$ The value of parameter " ${ }_{I}$ " (weight $\mathrm{x}$ score),

Nmaks $=$ Maximum value of continental saline habitat tourism category.

The suitability indexwas classified into three categories consisting of $\mathrm{N}=$ Not suitable, with a value of $<50 \%, \mathrm{~S} 2=$ Quite suitable, with a value of $50-75 \%$ and $\mathrm{S} 1=$ Suitable, with a value of $75-100 \%$ for parameters that could be estimated using percentage share.

Table 1: Matrix of continental saline habitats ecotouris m suitability

\begin{tabular}{|c|c|c|c|c|}
\hline Env. Parameters/category & & \multicolumn{3}{|c|}{ Score } \\
\hline & \multirow{2}{*}{ Weight } & 1 & 3 & 5 \\
\cline { 3 - 5 } & & N & S2 & S1 \\
\hline $\begin{array}{c}\text { Vegetation cover (VC) } \\
\text { Endemic/rare/attractive species } \\
\text { (NSp) }\end{array}$ & 5 & $<50 \%$ & $50-75 \%$ & $>75 \%$ \\
\hline Birds diversity (BD) & 3 & $<30 \%$ & $30-50 \%$ & $>50 \%$ \\
\hline $\begin{array}{c}\text { Protection status (PS) } \\
\text { Modified landscape (ML) }\end{array}$ & 3 & NOP & $\begin{array}{c}\text { NM, FOB, } \\
\text { SNR, }\end{array}$ & NtP, NP \\
\hline Acces ability (A) & 1 & ND/NR & ND/HR & D/HR \\
\hline Ecotourism facilities (EF) & 1 & NEF & IT & IT, VP, etc. \\
\hline
\end{tabular}

Note: Abbreviations: NOP - Not protected, NM - Natural monument, FOB - Features of outs tanding beauty, NtP - National park, SNR - Special nature res erve, NP - Nature park, ND - Not designed, NR - Not road, D - designed, HR - Have road, NEF - Not ecotouris $m$ facilities, IT - Info tables, VP - Viewpoints)

Source: Author's research

\section{Results and discussion}

The main parameters that were considered for the nature-based touris m suitability of continental saline habitats were selected according to similar studies that deal with the main factors of ecotourismattractiveness. The following 7 categories were assessed: vegetation cover, participation of endemic, rare and attractive flora, bird diversity as an important ecotouris mattraction, the status of protection, level of anthropogenic modification of original landscape, a factor of accessibility and existing ecotouris $m$ facilities or infras tructure. The weights and score values were given according to the importance of ecotouris m activities (Table 1). The values of each category were given based on fieldwork research described in 
Methods and represented in Table 2. Based on observation results, out of all criteria parameters related to suitability of saline habitats for nature-based tourism, Oblačinska s latina had the lowest ESI value of 45.3, while Rusanda had the highe st ESI value of 87.4. The matrix of nature-based tourismsuitability indicates that sites Slano Kopovo and Ru sanda are suitable (S1), while Lalinac is quite suitable (S2) and Oblačina, Bresničić and Alekdandrovac are not suitable $(\mathrm{N})$; The possible reas ons for such results lie in the fact that they are not protected, there are no information signs or boards which would inform the people about their location and significance and are considerably modified by anthropogenic impact.

Table 2: The suitability values of continental saline habitats categories for nature-based tourism

\begin{tabular}{|c|c|c|c|c|c|c|c|c|c|c|c|}
\hline $\begin{array}{l}\text { Research } \\
\text { site }\end{array}$ & $\begin{array}{c}\text { Sampling } \\
\text { point }\end{array}$ & \multicolumn{7}{|c|}{ Parameter/category } & $\sum$ & ESI & $\mathrm{SCg}$ \\
\hline & & VC & NSp & BD & PS & ML & $\overline{\mathbf{A}}$ & $\overline{E F}$ & & & \\
\hline $\begin{array}{l}\text { Slano } \\
\text { Kopovo }\end{array}$ & $\begin{array}{l}\text { Water, } \\
\text { Costal } \\
\text { Meadow }\end{array}$ & 75.0 & 70.0 & 74.0 & 70.0 & 10.00 & 90.0 & 10.0 & 79 & 83.2 & S1 \\
\hline Rusanda & $\begin{array}{l}\text { Water, } \\
\text { Costal } \\
\text { Meadow }\end{array}$ & 70.0 & 70.0 & 84.0 & 75.0 & 30.00 & 90.0 & 70.0 & 83 & 87.4 & S1 \\
\hline \multirow{4}{*}{$\begin{array}{c}\text { Southern } \\
\text { salines }\end{array}$} & Lalinac & 70.0 & 30.0 & 70.0 & 60.0 & 50.00 & 75.0 & 1.00 & 53 & 50.8 & $\mathrm{~S} 2$ \\
\hline & Oblačina & 60.0 & 40.0 & 70.0 & 1.00 & 75.00 & 75.0 & 51.0 & 43 & 45.3 & $\bar{N}$ \\
\hline & Bresničić & 55.0 & 60.0 & 70.0 & 1.00 & 75.00 & 1.00 & 1.00 & 47 & 49.5 & $\mathrm{~N}$ \\
\hline & $\begin{array}{c}\text { Aleksand } \\
\text { rovac }\end{array}$ & 60.0 & 55.0 & 65.0 & 1.00 & 75.00 & 50.0 & 10.0 & 47 & 49.5 & $\mathrm{~N}$ \\
\hline
\end{tabular}

Note: $\mathrm{SCg}$ - Suitability categ ory

Source: Author's research

\subsection{Vegetation cover and floristic attractiveness of continental saline habitats}

Natural resources are a very important component of the development of touris $m$ in general. Knowledge and assessment of natural res ources represent the basis for strategic plann ing and management of the potential tourismarea. Flora and vegetation are components of natural biological resources. Vegetation cover with endemic, rare and attractive species has the highest weightbecause it represents the key factor of attractiveness. According to Reichel et al. (2008), nature and landscape play an important role in attractiveness, including the wild flora and fauna, as well as the tradition and culture. Rare, endemic flora is very competitive for tourismattractions (Henri et al., 2017). As reported in the assessment study (Asrianny et al., 2020) of main ecotourismattractiveness, flora was identified as a very important factor in addition to natural features. Some strictly protected plants, among which are succulents Salicornia europaea, Suaeda pannonica, Suaeda maritima, Salsola soda, etc., are found on the territory of s aline habitats of Vojvodina, to which Slano Kopovo and Rus anda belong (Luković \& Dajić Stevanović, 2020). These plant species represent the main attraction and build a recognizable mosaic of the landscape together with evaporated salt crystals on the land surface. The second group of floris tic attractions includes salt-steppe meadows populated with Artemisia santocica that smells like the seaside. Besides the mentioned plants, many other endemic, rare and attractive species grow in this region such as Limonium gmelini, Plantago schwartzerbergiana, Plantago maritima, which are all considered important ecotourism objects as confirmed by other studies in the field of ecotourism (Brankov \& Žujović, 2008). A Ramsar site - Special Nature Reserve "Slano Kopovo" and the Nature Park "Rusanda" represent the last examples of the authentic Pannonian salt marshes with a wealth of flora and fauna (Čučulović et al., 2012). On the 
other hand, southern saline habitats are fragmented and mosaically distributed like small patches in total surroundings. They give a unique visual effect to the land scape. All Panonian saline habitats do not contain the same number of different species, however this does not diminis $h$ the floris tic value of sites. Several stu dies recognized and valorized salt marshes as a touristic potentialbased on the authenticity of a site, designation as a Ramsar site or the potential for local development (e.g., Brankov \& Žujović, 2012; Stojanović et al., 2018).

\subsection{Bird diversity}

Birdwatching is one of the acceptable recreational ecotourism activities since it seeks to observe wildlife (Rajević et al., 2016). It represents a very responsible and educational activity, and, as part of ecotourism, supports conservation of natural and cultural values of the local area, contributes to the development of the local community and brings important economic benefits (Son et al., 2011). Birdwatching is considered in numerous studies as a part of the ecotourismpackage (e.g., Suana et al., 2020). The most developed birdwatching market is in Great Britain and the Netherlands, while the most attractive destinations are exotic countries (Africa, Asia, Japan, India). Having in mind the fact that more than $70 \%$ of the bird fauna of Europe lives in Serbia, the country represents one of the potentially desirable locations for bird watching (Škvareninováet al., 2013). Centers of bird diversity in the Republic of Serbia are related to nature protected areas like NP Djerdap, NP Kopaonik, NP Golija etc., or Ramsar sites such as Peštersko polje, Vlasina, Gornje Podunavlje, Labudovo okno andZasavica. Saline lakes Slano Kopovo and Rus anda, as subjects of this research, are home to more than 200 bird species and important migratory stations. Especially interesting bird species are thin-beaked mallard, blue-billed duck, black float, little cormorant, and cranes. Floris tic and bird fauna characteris tics of saline lakes make the core bas is for suitability for nature-based tourism in these areas.

\subsection{Protected areas}

Protected areas with their natural beauties are identified as a key expressive attribute of ecotouris m satisfaction (Carvache-Franco et al., 2020). Three of the selected sites researched in this study were designated as protected areas: the Special Nature Reserve "Slano Kopovo", Nature Park "Rus anda" and Natural Monument "Lalinačka s latina". The rest of the studied sites are not under protection, notwithstanding their vulnerability and natural values. The status of protection determines the value/weight of the particular parameter and affects the final score; accordingly, the mentioned sites are considered suitable for nature-based tourism.

\subsection{Authenticity of lands cape}

Some studies reported the importance of original eco-landscape for ecotourism suitability assessment (Bunruamkaewa \& Muray amaa, 2011; Xiaolei et al., 2015). The results show that protected sites (Slano Kopovo and Rus anda) have the highest values (between 10\% and 30\% are modified) of the preserved original landscape, while saline habitats in the south are over $50 \%$ modified and under the intensive anthropogenic impact. According to Zlatković et al. (2005), these southern saline habitats are suffering the negative impacts of agriculture, pollution, and degradation. These human factors dis turb the originallandscape and diminish the natural value important for touris m development. 


\subsection{Community factors (accessibility and ecotourism facilities)}

Road network and infrastructure enable access to site points. Road accessibility was analyzed as one of the compulsory criteria for ecotourism suitability (Šiljeg et al., 2019). Developed road network and ecotourisminfras tructure can largely affect the economic improvement of tourist destination (Chandio et al., 2014). Slano Kopovo has a good position in terms of traffic infrastructure, due to main roads which facilitate access from the direction of Novi Bečej. In the vicinity of Slano Kopovo, in the $30 \mathrm{~km}$ to $50 \mathrm{~km}$ radius, the town of Kikinda and the city of Novi Sad are located. The Rusanda site is located near a small town of Melenci and gravitates towards Zrenjanin and Novi Sad. Both sites are equipped with basic ecotouris mfacilities such as information desks or small touris mfacilities. Researched sites in southern Serbia are les s developed in terms of road infrastructure. These sites are situated in villages and some of themdo not have direct access to major roads and are not marked by information or sign boards. Due to their geographical position, Lalinačka slatina, Oblačins ka slatina and Bresničić gravitate towards the city of Niš and the town of Prokuplje, while Aleks androvačka s latina gravitates towards the town of Vranje. The common characteris tic of all these areas is that they are not marked by information boards and do not have any ecotourist facilities. Analyzed community factors indicate that the Pannonian saline habitats are more suitable for nature-based tourism development. Investments in infrastructure represent one of the crucial activities and strategic advantages for any type of tourism development (Đorđević-Milošević et al., 2021).

\section{Conclusion}

In this paper, the authors analyzed two Pannonian saline habitats (Slano Kopovo and Rusanda) and four saline habitats situated in southern Serbia (Lalinačka slatina, Oblačinska slatina, Bresničić and Aleksandrovačka slatina) according to their nature-based tourism suitability. Continental saline habitats represent exceptionally valuable biodiversity areas, however, the public is generally not aware of their exis tence. Tourismdevelopment in these areas must support protection, education, and promotion of natural values in order to preserve saline habitats. According to the results, the Pannonian continental saline habitats belong to the S1 suitability category. Lalinačka Slatina belongs to the S2 category in terms of its suitability, while the rest of the southern Serbian saline habitats are not considered suitable for nature-based tourism.

Although the Pannonian saline habitats are in the S1 category thanks to their exceptional flora and bird fauna and authenticity of landscape, investments in improvement and promotion of eco-tourismfacilities are needed. The saline habitats in southern Serbia need to be further studied in the future period, as well as protected by the law and finally adequately promoted as potential nature-based sites.

\section{Acknowledgement}

Basic data on flora and vegetation, landscape, site management, etc., were collected thanks to the project "Sustainable Use and Management of Halophytic Gras slands as Key Element for Biodiversity Conservation", No. 9636-1 supported by Small research grants, Rufford foundation. Data process and analy zing were conducted with in bilateral collaboration SerbiaSlovenia, project "Multivariate biodiversity analys is and quality of natural grass lands in Western Balkans as the bas is for sustainable use", the Serbian Ministry of Education, Science and Technological Development. 


\section{Conflict of interest}

The authors declare no conflict of interest.

\section{References}

1. Asrianny, Soekmadi, R., Darusman, D., \& Arifin, H.S. (2020). Visitor perspectives and satisfaction index towards ecotourism potential in the Leang-Leang Prehistoric Park, Bantimurung Bulusaraung National Park. IOP Conference Series: Earth Environmental Science (pp. 1-12). IOP Publishing. https://doi.org/10.1088/1755-1315/528/1/012018

2. Barreira, L., Resek, E., Rodrigues, M. J., Rocha, M. I., Pereira, H., Bandarra, N., ... \& Custódio, L. (2017). Halophytes: Gourmet food with nutritional health benefits? Journal of Food Composition and Analysis, 59, 35-42. https://doi.org/10.1016/j.jfca.2017.02.003

3. Brankov, J., \& Žujović, B. (2008). Slano Kopovo - mogući pravci turis tičkog razvoja. [Slano Kopovo - possible direction of tourism development]. Glasnik Srpskog geografskog društva, 88(4), 91-98.

4. Braun-Blanquet, J. (1932). Pflanzensoziologie [Plant sociology]. Grundzüge der Vegetationskunde. Springer, Berlin.

5. Bueno González, M. (2020). Adaptation of halophytes to different habitats. In J. C. Jimenez-Lopez (Ed.), Seed Dormancy and Germination. Intech Open. https://doi.org/10.5772/intechopen.87056

6. Bunruamkaew, K., \& Murayam, Y. (2011). Site suitability evaluation for ecotourism using GIS \& AHP: A case study of Surat Thani Province, Thailand. Procedia - Social and Behavioral Sciences, 21, 269-278. https://doi.org/10.1016/j.sbspro.2011.07.024

7. Carvache-Franco, M., Carvache-Franco, O., \& Carvache-Franco, W. (2020). Exploring the satisfaction of ecotourism in protected natural areas. GeoJournal of Tourism \& Geosites, 29(2), 672-683. https://doi.org/10.30892/gtg.29223-498

8. Chandio, I. A., Matori, A. N., Yusof, K., Talpur, M. A. H., \& Aminu, M. (2014). GISbasedland suitability analysis of sustainable hillside development. Procedia Engineering, 77, 87-94. https://doi.org/10.1016/j.proeng.2014.07.009

9. Čučulović, R., Mrkša, M., Đekić, T., \& Čučulović, A. (2012). Mogućnosti razvoja turizma u srednjem Banatu [Opportunities for development of ecotourism in central Banat]. Bulletin of the Serbian geographical society, 92(3), 109-130. https://doi.org/10.2298/GSGD1203109C

10. Dagar, J. C. (2005). Ecology, management and utilization of halophytes. Bulletin of the National Institute of Ecology, 15, 81-97.

11. Dajić Stevanović, Z., Petrović, M., Šilc, U., \& Aćić, S. (2012). Database of halophytic vegetation in Serbia. Biodiversity and Ecology, 4, 417-417. https://doi.org/10.7809/be.00205

12. Đorđević, A., \& Radmanović S. (2016). Pedology. Belgrade: Faculty of Agriculture, University of Belgrade.

13. Đorđević-Milošević, S., Dražić, G., Milovanović, J., \& Đorđević, S. (2021). Strategic advantages and disadvantages for rural tourism development in Dinaric Alps/case Tropolje. Economics of Agriculture, 68(3), 701-712. https://doi.org/10.5937/ekoPolj2103701D.

14. Ecsedi,Z., Oláh J., \& Szegedi R. (2006). HabitatmanagementofHortobágy Ecoregion for bird protection. LIFE-Nature project of Hortobágy en vironmental as sociation 2002 2006. Laymans Report. 

ecosystems suitable for nature-based tourism? - Hotel and Tourism Management, 2021, Vol. 9, No. 2: 37-49.

15. González, M. B. (2020). Adaptation of halophytes to different habitats. In J. C. Jimenez-Lopez (Ed.), Seed Dormancy and Germination (pp. 1-23). Intech Open. https://doi.org/10.5772/intechopen.87056

16. Henri, H., Hakim, L., \& Batoro, J. (2017). The potential of flora and fauna as tourist attractions in Biodiversity Park of Pelawan Forest, Central Bangka. Biosaintifika: Journal of Biology \& Biology Education, 9(2), 240-247. https://doi.org/10.15294/BIOSAINTIFIKA.V9I2.9225

17. Johana, Y., Yuliandab, F., Kurniac, R., \& Muchsin, I. (2017). Analys is of marine ecotourism suitability for diving and snorkeling activities in Enggano Island. International Journal of Sciences: Basic and Applied Research (IJSBAR), 36(6), 202 212.

18. Lasabuda, R., Lohoo, A. V., \& Opa, E. T. (2019). Ecological suitability of mangrove ecotourism in Labuan Uki Bay, Bolaang Mongondow Regency, North Sulawesi Province, Indonesia. AES Bioflux, 11(1), 41-50.

19. Lowman, M. (2004). Ecotourism and treetops. In. M. Lowman \& H. B. Rinker (Eds.), Forest Canopies. Elsevier Academic Press. https://doi.org/10.1016/B978-0124575530/50032-0

20. Luković, M., Aćić, S., Šoštarić, I., Pećinar, I., \& Dajić Stevanović, Z. (2021). Management and ecosystem services of halophytic vegetation. In M. N. Grigore (Ed.), Handbook of Halophytes. Springer, Cham. https://doi.org/10.1007/978-3-030-57635$6 \_25$

21. Luković, M., \& Dajić Stevanović,Z. (2020). Saline habitats as undiscovered ecotourism attractions. In D. Cvijanović et al. (Eds.). Tourism in Function of Development of the Republic of Serbia - Tourism and Rural Development (pp. 246-263). Vrnjačka Banja: Faculty of Hotel Management and Tourism in Vrnjačka Banja.

22. Nash, J. (2001). Eco-tourism: Encouraging conservation or adding to exploitation? Retrieved October 3, 2021 from https://www.prb.org/resources/eco-tourismencouraging-conservation-or-adding-to-exploitation/

23. National Spatial Data Infrastructure (2021). Retrieved September 15, 2021 from https://a3.geosrbija.rs/

24. Nelly, C., Rasnovi, S., \& Zumaidar, Z. (2020). Mangrove ecosystem suitability for ecotourism management recommendation in Iboih Village - Sabang. E3S Web of Conferences: The 1st International Conference on Veterinary, Animal, and Environmental Sciences (ICVAES 2019) (pp. 1-6). https://doi.org/10.1051/e3sconf/202015101060

25. Nikalje, G. C., Bhaskar, S. D., Yadav, K., \& Penna, S. (2019). Halophytes: Prospective plants for future. In M. Hasanuzzaman et al. (Eds.), Ecophysiology, Abiotic Stress Responses and Utilization of Halophytes (pp. 221-234). Singapore, Springer. https://doi.org/10.1007/978-981-13-3762-8_1

26. O’Leary, J. W., \& Glenn, E. P. (1994). Global dis tribution and potential for halophytes. In V. R. Squires \& A. T. Ayoub(Eds.), Halophytes as a Resource for Livestock and for Rehabilitation of Degraded Lands. Tasks for Vegetation Science (pp. 7-17). Dordrecht, Springer. https://doi.org/10.1007/978-94-011-0818-8_2

27. Petropoulos, S. A., Karkanis, A., Martins, N., \& Ferreira, I. C. F. R. (2018). Edible halophytes of the Mediterranean basin: Potential candidates for novel food products. Trends in Food Science \& Technology, 74, 69-84. https://doi.org/10.1016/j.tifs.2018.02.006

28. Pin, T. G., Supriatna, J., Takarina, N. D., \& Tambunan, R. P. (2021). Mangrove diversity and suitability assessments for ecotourism in Cimalaya Wetan Coast, Karawang District, Indonesia. Biodiversitas, 22(2), 803-810. https://doi.org/10.13057/biodiv/d220234 
29. Raičević, Đ., \& Marjanović, M. (2021). Natural resources and regional development: Case study of the Gornje Polimlje region in Montenegro. Ekonomika, 67, 91-103. https://doi.org/10.5937/ekonomika2101091R

30. Rajević, S., Novaković-Kostić, R., \& Đuričić, M. (2016). Birdwatching tourism in Serbia.3rd International Conference - Higher Education in Function of Development of Tourism in Serbia and Western Balkans (pp.545-558). Business and Technical College of Vocational Studies, Užice.

31. Rančić, D., Pećinar, I., Aćić, S., \& Stevanović, Z. D. (2019). Morpho-anatomical traits of halophytic species. In M. Hasanuzzaman et al. (Eds.), Halophytes and Climate Change: Adaptive Mechanisms and Potential Uses. CABI. https://doi.org/10.1079/9781786394330.0152

32. Reed, P., \& Brown, G. (2003). Values suitability analysis: A methodology for identifying and integrating public perceptions of ecosystem values in forest planning. Journal of Environmental Planning and Management, 46(5), 643-658. https://doi.org/10.1080/0964056032000138418

33. Reichel, A., Uriely, N., \& Shani, A. (2008). Ecotourism and simulated attractions: Tourists' attitudes towards integrated sites in a desert area. Journal of Sustainable Tourism, 16(1), 23-41. https://doi.org/10.2167/jost711.0

34. Son, N. L. H., Dung, Le T., \& Van, N. T. (2011). Developing bird watching ecotourism combined with education and natural conservation. VNU Journal of Science: Earth and Environmental Sciences, 27(2), 89-97.

35. Srivarathan, S., Phan, A. D. T., Sultanbawa, Y., Wright, O., \& Netzel, M. E. (2020). Edible halophytes - A novel source of functional food ingredients? 1 st International Electronic Conference on Food Science and Functional Foods. Basel, Switzerland: MDPI. https://doi.org/10.3390/foods_2020-07822

36. Stojanović, V., Lazić, L., \& Dunjić, J. (2018). Nature protection and sustainable tourism interaction in selected Ramsar sites in Vojvodina (Northern Serbia). Geographica Pannonica, 22(3), 201-207. https://doi.org/10.5937/gp22-16637

37. Suana, I., Ahyadi, H., Hadiprayitno, G., Amin, S., Kalih, L. A., \& Sudaryanto, F. X. (2020). Environment carrying capacity and willingness to pay for bird-watching ecotouris m in Kerandangan Natural Park, Lombok, Indonesia. Biodiversitas, 21(5), 2266-2274. https://doi.org/10.13057/biodiv/d210557

38. Sánchez-Prieto, M. C, Luna-González, A., Espinoza-Tenorio, A., \& González-Ocampo, H. A. (2021). Planning ecotourism in coastal protected areas: Projecting temporal management scenarios. Sustainability, 13, 7528. https://doi.org/10.3390/su 13147528

39. Šefferová Stanová, V., Janák M., \& Ripka J. (2008). Management of Natura 2000 habitats. $1530 *$ Pannonic salt steppes and salt marshes. European Commis sion.

40. Šiljeg, A., Cavrić, B., Šiljeg, S., Marić, I., \& Barada, M. (2019). Land suitability zoning for ecotourism planning and development of Dikg at lhong Dam, Botswana. Geographica Pannonica, 23(2), 76-86. https://doi.org/10.5937/gp23-20633

41. Škvareninová, L., Lukinović, M., \& Jovanović, L. (2020). Potential of ecotourism: Comparative analysis of Slovakia and Serbia. LIMEN 2020 - Leadership, Innovation, Management and Economics: Integrated Politics of Research (pp. 121-132). https://doi.org/10.31410/LIMEN.S.P.2020

42. Tanto, T., Putra, A., Hermon, D., \& Damanhuri, H. (2018). Suitability of seagrass ecosystem for marine ecotourism in Padang City, West Sumatera Province. Forum Geografi, 32(1), 88-95. https://doi.org/10.23917/forgeo.v32i1.5306

43. Tomić, S., Leković, K., Eskerod, P., \& Zedlacher, E. (2020). Profile of rural tourism consumers in Serbia and Austria. Anali Ekonomskogfakulteta u Subotici, 56(44), 81-95. https://doi.org/10.5937/AnEkSub2044081T

44. Xiaolei, Z. Zhaoping, Y., Wenmin, Q., Fang W., \& Cuirong, W. (2015). Ecotourism suitability and zoning fromthe touris t perspective: A nature reserve case study. Polish 

ecosystems suitable for nature-based tourism? - Hotel and Tourism Management, 2021, Vol. 9, No. 2: 37-49.

Journal of Environmental Studies, 24(6), 2683-2697.
https://doi.org/10.15244/pjoes/59422

45. Zhao, K., Song, J., Feng, G., Zhao, M., \& Liu, J. (2011). Species, types, distribution, and economic potential of halophytes in China. Plant Soil, 342, 495-509. https://doi.org/10.1007/s 11104-010-0470-7

46. Zlatković, B., Ranđelović, V., \& Amidžić, L. (2005). Flora i vegetacija slatina centralne i južne Srbije i njihova valorizacija sa aspekta zaštite [Flora and vegetation of central and south Serbia with aspect of nature protection valorisation].Zavod za zaštitu prirode Srbije. 